\title{
浅水流方程式と平衡流砂量式を基本とした 河床変動計算モデルに関する検討
}

\author{
岩崎理樹 ${ }^{1} \cdot$ 清水康行 $^{2} \cdot$ 木村一郎 ${ }^{3}$ \\ 1 正会員 北海道大学工学研究院 ( $\bar{T}$ 060-8628 北海道札幌市北区北 13 条西 8 丁目) \\ E-mail: t_iwasaki@eng.hokudai.ac.jp \\ 2 正会員 北海道大学教授 工学研究院 (同上) \\ 3 正会員 北海道大学准教授 工学研究院 (同上)
}

\begin{abstract}
本研究では, 浅水流方程式と平衡掃流砂量式を基本とした河床変動モデルの特性と安定性について, 微小な河 床擾乱の伝搬計算を通じて検討を行った. 方程式系を線形化することで, 河床擾乱の伝搬を示す双曲型微分方程 式を導出し, 河床擾乱の伝搬特性について明らかにした。この時, 平衡流砂量式の枠組みでモデル化される流 砂量に対する局所勾配の影響は河床擾乱を拡散させる作用を持つ. 双曲型方程式を安定的に計算する条件であ る Péclet 数が 2 以下となる条件を満たすように格子幅を設定すれば，流砂量の空間微分に対して風上化を導入 せずとも，方程式が持つ不安定性を合理的に散逸させつつ，安定的な河床変動計算を実行できることを示した.
\end{abstract}

Key Words : shallow water flow model, equilibrium bed load formula, computational model, bed slope effect, Péclet number

\section{1.はじめに}

計算機と数值計算技術の発達により，河川工学分野 においても河川流とそれに伴う河床変動・河岸侵食過 程を再現する数值計算モデルの構築が積極的に行われ てきた. 河床変動モデルの構築は, 不等流モデルと平 衡流砂量式を基本とした河川の縦断的な河床変動を扱 う一次元モデル ${ }^{1)}$ に始まり, 平面的な河床変動を計算す る二次元モデルへの拡張2),3)が行われ, 工学的なツール として大きく発展してきた. 同時に，流体モデルや流 砂モデルの深化に伴い, 精緻な乱流モデルを組み合わ せた鋁直二次元モデル4)や三次元モデル5) と, 非平衡流 砂モデルを組み合わせたより実現象を表現可能なモデ ルの開発が展開されている。近年では，土粒子の移動 をラグランジュ的に追跡することにより, 河床の連続 体仮定や流砂モデルを陽に用いずに地形変動を計算す るモデル6),7),8) も構築され, 流体 - 土砂粒子移動に伴う 地形変動現象がより深く理解されることが期待される. 一方で, モデルの精密化, 高度化及び計算の大規模化 に伴う計算機負荷の増大は, 長期間の河床変動計算は もとより一洪水を対象としても無視できるものではな い. これは急速な計算機関連技術の発達をもってして も直ちに解決できる問題ではないため, 工学的な適用 範囲は限定されることとなる。それゆえ現段階におい ては, 要求される現象に応じてモデルを選択せざるを 得ず，そのような面からすれば，浅水流方程式と平衡 流砂量式による河床変動モデルはバランスのとれた解
析ツールであると考えられる。また，このモデルは河 川のリーチスケールの河床変動・河岸侵食を解析する 際に重要となる, 砂州や蛇行といった河川が潜在的に 有する不安定現象を表現できることが解析的に明らか にされている99,10)。これらの方程式をべースに, 詳細 な要素モデルを追加していくことで, ある程度の精度 を持って大局的な河川の河床変動を表現できることが 期待される.

しかしながら, 数值計算力学を背景とした河床変動 計算の安定性については, 流れ場の計算と比較して十 分に検討されていないと考えられる。 そのような背景 からか, 河床変動モデルの離散化, 安定性, 高精度化に ついては流砂モデルの選択と比較してそれほど重視さ れていない。黒木ら 11 は, 流れ場を不等流, 掃流砂運動 を平衡流砂量式で表した河床変動モデルに対して, こ れらを連立させた方程式が，河床高に対する双曲型方 程式であることを示した. この時, 河床擾乱の伝搬方向 はフルード数により規定され，常流の場合は下流，射 流の場合は上流に伝わる小規模河床波的な性質を持つ. このような性質を利用し, 河床連続式における流砂量 の空間微分に対して, 常流では後退差分, 射流では前進 差分とする風上化を導入することにより, 安定的な河床 変動計算が可能となることが示されている.また，大川 $ら^{11)}$, 西本ら ${ }^{12)}$ は非定常浅水流方程式と平衡流砂量モ デルを組み合わせた方程式系に対して Flux Difference Splitting (FDS) 法13)を適用することにより，常射流混 在場においても安定的に計算可能な河床変動モデルを 
提案した。これらのモデルではFDS 法の性質より, 理 論的に流れ, 流砂量の風上化が導入される点が有利で ある．特に西本らは，これらの方程式系を移流方程式 として考えることにより，3つの特性速度があることを 示した，すなわち，先に示した不等流モデルを仮定し て得られる河床擾乱の伝搬機構とは別に，流孔場から 規定される河床擾乱の伝搬機構を示し，この性質によ り, 不等流モデルではフルード数が 1 となる臨界点に おいて風上化が定義できないという従来の計算モデル の欠点が取り除かれることを示した. Goutiére et al. ${ }^{14)}$ も西本らと同様のモデル方程式から同様の伝搬機構に ついて考察を行い, 計算手法としては Harten, Lax and van Leer (HLL) 法15)を用いることで, 安定的な河床 変動モデルを構築している。 一方, Hudson et al. ${ }^{16)}$, Long et al. ${ }^{17)}$ は河床変動方程式の風上差分を高精度化 する為に, 双曲型微分方程式の数值解法に用いられる Weighted Essentially Non-Oscillatory (WENO) 法 ${ }^{18)}$ を流砂量の差分に適用し, より数值粘性の少ない計算 法を提案している. また, Cordier et al. ${ }^{19)}$ は, 河床変 動計算において, 流れと河床変動の計算を分離して解 く場合, CFL 条件が厳しい条件において計算が不安定 になることを示している。このような高精度で安定な 河床変動計算法は二次元モデルへの拡張が行われ, 砂 州や分岐部の河床変動計算に適用されている ${ }^{20)}$.

このように，河床変動の擾乱の伝搬を安定的に計算 するには, 河床変動方程式が持つ双曲型の性質を考慮 し, 河床連続式の流砂量空間微分を適切な形で風上化 を導入することが重要であり, 数多くの数值計算モデ ルでもこのような差分方法が適用されている ${ }^{21)}$. しか しながら，このような検討では通常数值安定性に関す る議論に重点が置かれ，風上化が河床変動に対してど の程度の影響を与えるかについてはそれほど検討され ていない，また，本来掃流砂を基本とした河床変動は 拡散的であることが知られている。これは, 流砂量に 対して局所的な河床勾配の影響が作用するためである. したがって, 不適切な風上化では数值拡散により河床は 安定するものの, 物理的な拡散作用による河床変動を 十分に考慮することができない場合も起こり得る。こ のような観点から, 双曲型方程式を安定化させるため に必要な風上化による数值拡散と, 本来流砂現象に内 在する河床勾配の影響から導入される物理的な拡散作 用の関連については議論しておくことが望ましいとい える. 特に, ここで議論した河床擾乱の伝搬方向から 分かるように, この性質は小規模河床波と同様のもの であり, 浅水流方程式と平衡流砂量式からなる河床変 動モデルでは減衰すべき不安定成分である. 準三次元 モデルや非平衡モデルの導入を図らずに, 数值的な不 安定性により小規模河床波のような河床波が計算され
てしまえば，数值解の信頼性は著しく低下寸ることと なる.また, このようなモデルの性能, 適用範囲を理 論的な背景の下で確立しておけば，将来的に流砂現象 の素過程の解明が進み, これを利用した現在よりも合 理的な流砂量モデルが構築された際に, より信頼性の 高い河床変動モデルが構築できることとなる.

本研究は, 一般に広く用いられる浅水流方程式と平 衡流砂量式を用いた河床変動モデルの計算法について, 河床擾乱の伝搬機構に対する計算を通じて考察するも のである. 河床擾乱の伝搬機構と安定性を議論するた めに, 方程式を線形化し，擾乱の伝搬を表現する双曲型 の河床変動方程式を導出する.この線形化方程式から, 風上化により導入される数值的な拡散作用と流砂に対 する河床勾配の影響から導入される物理的な拡散作用 の関係について明らかにし, 格子幅を適切に選択寸れ ば流砂量の空間微分に風上化を導入せずとも安定的な 河床変動計算を行うことができることを示す. 最後に, 流砂量に対する河床勾配効果のモデル化の違いが, 上 記議論にどのような影響を及ぼすかについて, 流砂量 式として Meyer-Peter and Müller 式 ${ }^{22)}$ に河床勾配項を 導入した Fredsøe 式23) と Kovacs and Parker 式 ${ }^{24)}$ 取 り上げ考察を行う。

\section{2. モデルと安定性}

\section{（1）基礎方程式}

本研究では, 簡単のために 1 次元の河床擾乱の伝搬 機構について検討を行う。流れの支配方程式は, 以下 に示寸 1 次元浅水流方程式である.

$$
\begin{gathered}
\frac{\partial \tilde{h}}{\partial \tilde{t}}+\frac{\partial \tilde{u} \tilde{h}}{\partial \tilde{x}}=0 \\
\frac{\partial \tilde{u}}{\partial \tilde{t}}+\tilde{u} \frac{\partial \tilde{u}}{\partial \tilde{x}}=-g \frac{\partial \tilde{h}}{\partial \tilde{x}}-g \frac{\partial \tilde{z}}{\partial \tilde{x}}-C_{f} \frac{\tilde{u}|\tilde{u}|}{\tilde{h}}
\end{gathered}
$$

ここに, $\tilde{t}$ : 時間, $\tilde{x}$ : 流下方向軸, $\tilde{u}$ : 水深平均流速, $\tilde{h}$ : 水深, $\tilde{z}:$ 河床高, $g$ : 重力加速度 $\left(=9.8 \mathrm{~m} / \mathrm{s}^{2}\right)$ 及び $C_{f}$ : 抵抗係数であり, 粗面の対数則を仮定すると以下のよ うになる。

$$
C_{f}=\left[6+\frac{1}{\kappa} \ln \frac{\tilde{h}}{\tilde{k_{s}}}\right]^{-2}
$$

ここに, $\kappa$ : カルマン定数 $(=0.41), \tilde{k_{s}}$ : 河床面の相対 粗度高さで, 本研究では河床材料粒径の 2.5 倍と寸る. なお, 洧次元の変数を意味する.

流砂モデルは，Freds $\varnothing \mathrm{e}^{23)}$ が提案した河床勾配の影響 を考慮した Meyer-Peter and Müller 式22)を用いる.

$$
\frac{\tilde{q_{b}}}{\sqrt{s g \tilde{d}^{3}}}=A\left[\tau_{*}-\tau_{* c}\left(1+\frac{1}{\mu_{c}} \frac{\partial \tilde{z}}{\partial \tilde{x}}\right)\right]^{3 / 2}
$$

ここに, $\tilde{q_{b}}$ : 掃流砂量, $\tau_{*}$ : シールズ数, $\tau_{* c}$ : 限界シー ルズ数, $s$ : 土粒子の水中比重, $\tilde{d}$ : 土粒子の粒径及び 
$\mu_{c}$ : クーロン動摩擦係数である. Freds $\varnothing \mathrm{e}^{23)}$ は, 河床勾 配の影響度合を表すパラメータを $\tau_{* c} / \mu_{c}$ とし，これが 0.1 程度の值となることを述べている. 式 (4)の形では, このパラメータは限界掃流力と土粒子の摩擦係数 $\mu_{c}$ か ら決定される. $\mu_{c}$ は土粒子の安息角 $\phi$ に関連づけられ, $\mu_{c}=\tan \phi$ となるといわれている ${ }^{24)}$. 土粒子の安息角は およそ 30〜 40であるため, $\mu_{c}$ は $0.58 \sim 0.84$ 程度の值 をとることになる. Fredsøe は, $\tau_{* c}=0.047$ としたた め, $\mu_{c}$ は 0.47 と仮定していることになる ${ }^{25)}$.この值 は土粒子の安息角の観点からすると若干小さな值では あるが, 非物理的な值ではないため, 本研究でも $\mu_{c}$ を 0.47 と設定した。 なお, 限界シールズ数は岩垣式 ${ }^{26) に ~}$ より求めることとした，従って， $\mu_{c}$ が固定值の場合, 河 床勾配の影響度合を表すパラメータが限界シールズ数 により変化することとなるが, Kovacs and Parker 式と の比較を明確にするために，ここでは $\mu_{c}$ を固定值とし て扱うこととした。

河床連続式は掃流砂のみを考慮した以下の Exner 式 を用いる。

$$
\frac{\partial \tilde{z}}{\partial \tilde{t}}+\frac{1}{1-\lambda_{p}} \frac{\partial \tilde{q_{b}}}{\partial \tilde{x}}=0
$$

ここに, $\lambda_{p}$ : 河床空隙率である.

\section{（2）線形化方程式}

後に行う数值計算は前節に示した非線形方程式をそ のまま用いるが，基礎方程式の安定性や離散化につい て検討するために, 線形化方程式を導出する. これに より, 微小な河床擾乱の伝搬機構についての考察が可 能となる.なお，ここでは簡単のため流れの方程式に 対しては河床変動の時間スケールに対して流れの時間 スケールが十分短いとする準定常近似を適用すること にする.

まず，基本変数に対して以下の無次元化を行う.

$$
\begin{gathered}
\tilde{x}=\frac{\tilde{h}_{0}}{i_{b}} x, \quad \tilde{u}=\tilde{u}_{0} u, \quad(\tilde{h}, \tilde{z})=\tilde{h}_{0}(h, z) \\
\tilde{t}=\tilde{T} t, \quad \tilde{q_{b}}=\tilde{q}_{b 0} q_{b}
\end{gathered}
$$

ここで， $i_{b}$ : は平均河床勾配であり, 添え字 0 は等流状 態の值を意味する。また，

$$
\begin{gathered}
\tilde{T}=\left(1-\lambda_{p}\right) \frac{\tilde{h}_{0}^{2}}{\tilde{q}_{b 0} i_{b}} \\
q_{\tilde{b} 0}=A\left[\tau_{* 0}-\tau_{* c}\left(1-\frac{i_{b}}{\mu_{c}}\right)\right]^{3 / 2} \sqrt{s g \tilde{d}^{3}} \\
\tau_{* 0}=\frac{C_{f 0} \tilde{u}_{0}^{2}}{s g \tilde{d}} \\
C_{f 0}=\left[6+\frac{1}{\kappa} \ln \frac{\tilde{h}_{0}}{\tilde{k}_{s}}\right]^{-2}
\end{gathered}
$$

と定義する.これらを式 $(1) 〜(5)$ に代入することによ り, 以下の無次元化された式を導くことができる.

$$
\begin{gathered}
\frac{\partial u h}{\partial x}=0 \\
u \frac{\partial u}{\partial x}=-\frac{1}{F_{r}^{2}} \frac{\partial h}{\partial x}-\frac{1}{F_{r}^{2}} \frac{\partial z}{\partial x}-\frac{C_{f 0}}{i_{b}} \frac{u|u|}{h C_{f h}} \\
q_{b}=\left[\frac{\tau_{* 0} \frac{u^{2}}{C_{f h}}-\tau_{* c}\left(1+\frac{i_{b}}{\mu_{c}} \frac{\partial z}{\partial x}\right)}{\tau_{* 0}-\tau_{* c}\left(1-\frac{i_{b}}{\mu_{c}}\right)}\right]^{3 / 2} \\
C_{f h}=\left(1+\frac{1}{\kappa} C_{f 0}^{1 / 2} \ln h\right)^{-2} \\
\frac{\partial z}{\partial t}+\frac{\partial q_{b}}{\partial x}=0
\end{gathered}
$$

ここに, $F_{r}:$ 等流状態のフルード数であり,

$$
F_{r}=\frac{\tilde{u}_{0}}{\sqrt{g \tilde{h}_{0}}}
$$

である。

ここで，等流状態に対して以下のような摂動を与える.

$$
(u, h, z)=(1,1,-x)+\left(u_{1}, h_{1}, z_{1}\right)
$$

ここで, 添え字 ${ }_{1}$ は 1 次オーダーの摂動を意味する.こ の摂動を式 (12)〜 (16) に示す無次元方程式に代入し線 形化を行えば, 以下の 1 次オーダーの方程式が得られる.

$$
\begin{gathered}
\frac{\partial u_{1}}{\partial x}+\frac{\partial h_{1}}{\partial x}=0 \\
\frac{\partial u_{1}}{\partial x}=-\frac{1}{F_{r}^{2}} \frac{\partial h_{1}}{\partial x}-\frac{1}{F_{r}^{2}} \frac{\partial z_{1}}{\partial x} \\
-\frac{C_{f 0}}{i_{b}}\left[2 u_{1}-\left(1+\frac{1}{\kappa} C_{f 0}\right) h_{1}\right] \\
q_{b 1}=3 \frac{\tau_{* 0}}{\theta_{01}} u_{1}-\frac{3}{2 \kappa} C_{f 0}^{1 / 2} \frac{\tau_{* 0}}{\theta_{01}} h_{1}-\frac{3}{2} \frac{\tau_{* c} i_{b}}{\mu_{c} \theta_{01}} \frac{\partial z_{1}}{\partial x} \\
\frac{\partial z_{1}}{\partial t}+\frac{\partial q_{b 1}}{\partial x}=0
\end{gathered}
$$

ここに,

$$
\theta_{01}=\tau_{* 0}-\tau_{* c}\left(1-\frac{i_{b}}{\mu_{c}}\right)
$$

である. 式 (19) を式 (20) に, 式 (19), (21) を式 (22) に代入すれば以下のようになる。

$$
\begin{gathered}
\frac{\partial h_{1}}{\partial x}=-\frac{1}{1-F_{r}^{2}} \frac{\partial z_{1}}{\partial x}+\frac{F_{r}^{2}}{1-F_{r}^{2}} \frac{C_{f 0} C_{f 2}}{i_{b}} h_{1} \\
\frac{\partial z_{1}}{\partial t}-3 C_{f 1} \frac{\tau_{* 0}}{\theta_{01}} \frac{\partial h_{1}}{\partial x}=\frac{3}{2} \frac{\tau_{* c} i_{b}}{\mu_{c} \theta_{01}} \frac{\partial^{2} z_{1}}{\partial x^{2}} \\
C_{f 1}=1+\frac{1}{2 \kappa} C_{f 0}^{1 / 2} \\
C_{f 2}=3+\frac{1}{\kappa} C_{f 0}^{1 / 2}
\end{gathered}
$$

これらをまとめれば, 最終的に黒木ら ${ }^{1)}$ が示した河床変 動方程式を線形化した微分方程式が得られる.

$$
\begin{aligned}
\frac{\partial z_{1}}{\partial t} & +\frac{3}{1-F_{r}^{2}} C_{f 1} \frac{\tau_{* 0}}{\theta_{01}} \frac{\partial z_{1}}{\partial x} \\
& =\frac{F_{r}^{2}}{1-F_{r}^{2}} S_{o} h_{1}+\frac{3}{2} \frac{\tau_{* c} i_{b}}{\mu_{c} \theta_{01}} \frac{\partial^{2} z_{1}}{\partial x^{2}}
\end{aligned}
$$




$$
S_{o}=\frac{3}{i_{b}} \frac{\tau_{* 0}}{\theta_{01}} C_{f 0} C_{f 1} C_{f 2}
$$

\section{（3）河床擾乱の伝搬機構と安定条件}

式 (28) の微分方程式は，ソース項を含む移流拡散型 の方程式であることがわかる．左辺第二項が，擾乱の 伝搬を示寸移流項となり，伝搬方向は従来の理論から 明らかなように $F_{r}<1$ の時は下流， $F_{r}>1$ の時は上流 となる。また，右辺第二項は流砂量に対する局所勾配 の影響から導出される項であり, 常に正の拡散係数を 持つ拡散項であるため, 伝搬する河床擾乱は次第に拡 散することとなる。

式 (28) が示すように, 浅水流方程式と平衡流砂量式 を組み合わせた河床変動計算モデルにより計算を行う 際には，流砂量空間微分の風上化と局所勾配による河 床の拡散作用が重要な意味を持つ. 移流拡散方程式を 安定的に計算するためには，移流と拡散度合の比であ る Péclet 数, $P_{e}$ が 2 以下である必要がある.

$$
P_{e}=\frac{\frac{3 C_{f 1}}{\left|1-F_{r}^{2}\right|} \frac{\tau_{* 0}}{\theta_{01}}}{\frac{3}{2} \frac{\tau_{* c}}{\mu_{c} \theta_{01}} \frac{1}{\Delta x}}=\frac{\mu_{c} C_{f 1}}{i_{b}} \frac{\tau_{* 0}}{\tau_{* c}} \frac{2 \Delta x}{\left|1-F_{r}^{2}\right|}<2
$$

この条件は，式 $(28)$ 左辺第二項を風上化した際に現れ る数值拡散項の係数が右辺第二項に示す流砂量に対す る局所河床勾配の影響を考慮することにより得られる 物理的な拡散項の係数より小さくなる条件である.す なわち, 式 (28) における河床擾乱の伝搬速度を

$$
V_{z}=\frac{3}{1-F_{r}^{2}} C_{f 1} \frac{\tau_{* 0}}{\theta_{01}}
$$

と置くと，この移流項に対して風上差分を適用すれば， 以下のようになる.

$$
\begin{aligned}
& V_{z} \frac{\partial z_{1}}{\partial x}=V_{z} \frac{z_{1(i+1)}-z_{1(i-1)}}{2 \Delta x} \\
& \quad-\frac{\left|V_{z}\right|}{2} \Delta x \frac{z_{1(i+1)}-2 z_{1(i)}+z_{1(i-1)}}{\Delta x^{2}}
\end{aligned}
$$

このように風上化により $\left|V_{z}\right| \Delta x / 2$ の拡散係数を持つ数 值拡散項が現れる。風上化による拡散作用が物理的な 拡散作用よりも小さくなる条件は, 式 (28), (32) より

$$
\frac{3}{2} \frac{C_{f 1}}{\left|1-F_{r}^{2}\right|} \frac{\tau_{* 0}}{\theta_{01}} \Delta x<\frac{3}{2} \frac{\tau_{* c} i_{b}}{\mu_{c} \theta_{01}}
$$

であり，この条件は式 (30) と等価である。陽解法にお ける一次精度の風上差分は, CFL 条件を満たしている 限り，時間とともに誤差が増幅しないTVD 条件を常に 満足するため, 式 (30) は双曲型方程式である河床変動 方程式を安定に計算するための必要条件であると考え ることができる。

導入している無次元化より,

$$
\tilde{\Delta x}=\frac{\tilde{h}_{0}}{i_{b}} \Delta x
$$

であるから,$P_{e}=2$ となる臨界点を満たす条件は次式 となる。

$$
\tilde{\Delta x_{P_{e}=2}}=\frac{\left|1-F_{r}^{2}\right|}{\mu_{c} C_{f 1}} \frac{\tau_{* c}}{\tau_{* 0}} \tilde{h}_{0}
$$

上式で定義される格子サイズを満足していれば，流砂 量の空間微分に対して風上化を導入せずとも，河床勾 配項による拡散効果により，河床の数值不安定性を抑 制して解析できると考えられる。この条件によれば流 砂量に風上化を導入しない場合， $\mu_{c}$ が大きい $(=$ 勾配の 影響が小さい)， $F_{r}$ が 1 に近い， $\tau_{* 0}$ が大きい，水深が 小さいほど，格子サイズを小さくとる必要がある.

なお， $F_{r}=1$ では格子サイズが無限小となるうえ，流 砂量の風上化を定義できなくなる。これは，西本ら ${ }^{12)}$, Goutiére et al. ${ }^{14)}$ の解析から分かるように, 流れのモ デルに準定常仮定を導入したためであり，非定常項を 残して解析すれば，このような不具合は取り除かれる. この点については, 後の計算結果において確認するこ とができる。

\section{3. 数値計算}

前節に示した安定計算に要求される格子サイズと風 上化による拡散の影響, 局所勾配による拡散の影響に ついていくつかの数值計算により議論を行う.

\section{(1) 数値計算法}

数值計算に用いるモデルは，式 $(1) 〜(5)$ に示す非線 形方程式である.すべての基礎式はスタッガード格子上 で離散化される.流れのモデルについては，Jang and $\mathrm{Shimizu}^{27)}$ と同様に, 運動方程式に分離解法を適用し て，非移流項と連続式を連立計算したのちに，移流項 について CIP 法を適用している.

流れのモデルの離散化については上記で統一し，河 床変動モデルの離散化と流砂量式の組み合わせにより 3 つのモデルを作り，その結果を比較する。まず，式 (5) に示す河床連続式中の流砂の空間微分に中央差分，式 (4)に示す流砂量式には局所勾配の影響を考慮しない本 来の Meyer-Peter and Müller 式を用いたものを Model 1 とする. 次に, 流砂の空間微分に式 (28) から議論され た風上差分, 流砂量式に Model 1 と同様に Meyer-Peter and Müller 式を用いたものを Model 2 とする. 最後に, 流砂の空間微分に中央差分, 流砂量式に勾配の影響を 考慮した Meyer-Peter and Müller 式を適用したものを Model 3 とする. Model 1 と Model 2 の比較により, 河 床変動計算に対する風上化の影響を, Model 2 と Model 3 の比較により，数值的な拡散作用と物理的な拡散作用 の関係を議論することができる。これらをまとめると 表-1のようになる.

また，流砂の空間微分について図-1に示す変数配置 
表-1 流砂空間微分の差分方法と流砂モデルの組み合わせ

\begin{tabular}{llc}
\hline & $\begin{array}{c}\text { 流砂空間微分の } \\
\text { 差分方法 }\end{array}$ & $\begin{array}{c}\text { 流砂への } \\
\text { 河床勾配の影響 }\end{array}$ \\
\hline Model 1 & 中央差分 & 無 \\
Model 2 & 風上差分 & 無 \\
Model 3 & 中央差分 & 有 \\
\hline
\end{tabular}

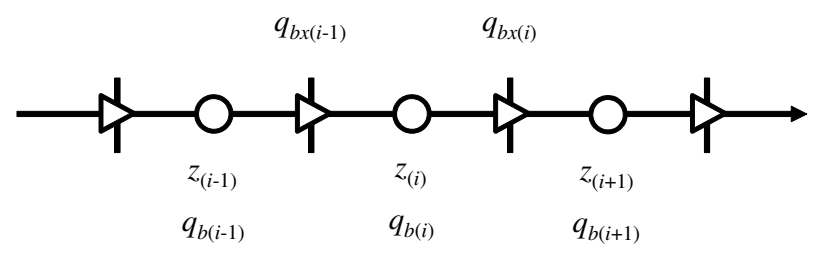

図-1 流砂量の定義点

を基に説明を行う．なお，次元量を示す は省略してい る. 流砂の空間微分を中央差分とする場合は，セル境 界で流砂量 $q_{b x}$ を定義し以下のように離散化するのが 合理的である.

$$
\frac{\partial q_{b}}{\partial x}=\frac{q_{b x(i)}-q_{b x(i-1)}}{\Delta x}
$$

一方で，風上差分を用いる場合，流砂量はセル中央で 定義し以下のように離散化する。

$$
\begin{aligned}
\frac{\partial q_{b}}{\partial x} & =\frac{q_{b(i)}-q_{b(i-1)}}{\Delta x} & & F_{r}<1 \\
& =\frac{q_{b(i+1)}-q_{b(i)}}{\Delta x} & & F_{r}>1
\end{aligned}
$$

中央差分を用いる場合は，差分間隔を $2 \Delta x$ とした

$$
\frac{\partial q_{b}}{\partial x}=\frac{q_{b(i+1)}-q_{b(i-1)}}{2 \Delta x}
$$

という差分形式も考えられるが，式 (36) のほうがより コンパクトなスキームであると共に, 流砂量関数中の 局所勾配を計算する際にスタッガード格子の利点を生 か寸ことができるため, 中央差分には式 (36) の形式を 採用する.

\section{(2) 計算条件}

本研究では, 一定勾配の河床に波長 $2 \mathrm{~m}$, 波高が水深 の $1 \%$ 程度の微小擾乱を与え, この伝搬について計算を 行う. 式 $(28)$ より, 河床擾乱の伝搬速度は $F_{r}$ と $\tau_{* 0} / \theta_{01}$ に影響を受けるが， $\tau_{* 0} / \theta_{01}$ は $\tau_{* 0}$ が大きくなるにつれ て 1 に近づくため, 影響度合いは小さい. そこで, $F_{r}$ を変化させた 4 ケースの数值計算を行った。また，風 上化による河床の拡散作用と局所勾配による物理的な 拡散作用の影響を見るためには，上述の $\tilde{\Delta x_{P_{e}}=2}$ と設 定する格子幅の関係が重要となる。ここでは, $\tilde{\Delta} x_{P_{e}=2}$ を $F_{r}=1$ 以外のケースで $0.05 \mathrm{~m}$ 程度になるように条 件を調節し, 設定格子幅を $0.01,0.05$ 及び $0.2 \mathrm{~m}$ と変
表-2 計算ケース

\begin{tabular}{cccccc}
\hline & $F_{r}$ & $\tau_{* 0}$ & $\tilde{d}(\mathrm{~mm})$ & $\tilde{h}_{0}(\mathrm{~m})$ & $i_{b}$ \\
\hline Case 1 & 0.64 & 0.48 & 0.8 & 0.62 & $1 / 1000$ \\
Case 2 & 0.89 & 1.4 & 2.68 & 3.72 & $1 / 600$ \\
Case 3 & 1 & 1.02 & 4 & 2.7 & $1 / 400$ \\
Case 4 & 1.15 & 3.37 & 2.6 & 5.78 & $1 / 400$ \\
\hline
\end{tabular}

化させ計算結果の違いを考察する. $F_{r}=1$ においては,

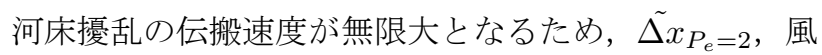
上化を定義することもできなくなる．これらをまとめ ると表-2 となる. なお，ここでは河床擾乱の伝搬計算 に対するモデルの特性と安定性について議論するため, 理論值や実験值とは比較を行わないこととする。これ は, 非線形の理論解が得難いことと, ここで検討する 河床擾乱の伝搬を実験により再現することが困難であ るためである.

\section{4. 結果と考察}

\section{(1) 計算結果}

a) Case 1, $2 \quad\left(F_{r}<1\right)$

図-2，3に，それぞれの計算条件における河床擾乱の 伝搬過程に関する結果を示す．流れが常流である Case 1, 2 では, 式 (28) から示唆されるように, 河床擾乱が 下流に伝搬している様子が理解できる。 この時, 本来 不安定である中央差分を用いた Model 1 の結果を見る と格子幅が小さい場合は, 安定して計算が行われてい るが, 格子幅が大きい場合は河床擾乱が振動し, 特に Case 1 において不安定性が顕著である.この河床が振 動する振幅は, フルード数が小さい Case 1 のほうが大 きく, Case 2 では不安定性が次第に収束している様子 が確認できる. 一方, 風上差分を用いた Model 2 では, 河床擾乱の拡散度合は格子幅により大きく異なり，格 子幅が小さいケースでは Model 1 に近く, 格子幅が最 大のケースでは河床はほぼ平坦に近づく，また，流砂 量の差分に中央差分, 流砂量式に Fredsøe 式を適用し た Model 3 では，全体的に計算結果に対する格子幅依 存性が小さいことがわかる.

\section{b) Case $3 \quad\left(F_{r}=1\right)$}

図-4に，フルード数が 1 の臨界条件である Case 3 の 結果を示す.フルード数が 1 の条件では, 河床擾乱は 上下流に同一の速度，振幅を持って伝搬していること がわかる.この特性については, 式 (28) からは説明で きないが，西本らが非定常の浅水流方程式を用いて示 した結果と同様である。計算結果から明らかなように, このケースでは計算格子幅にかかわらず, Model 1 と 

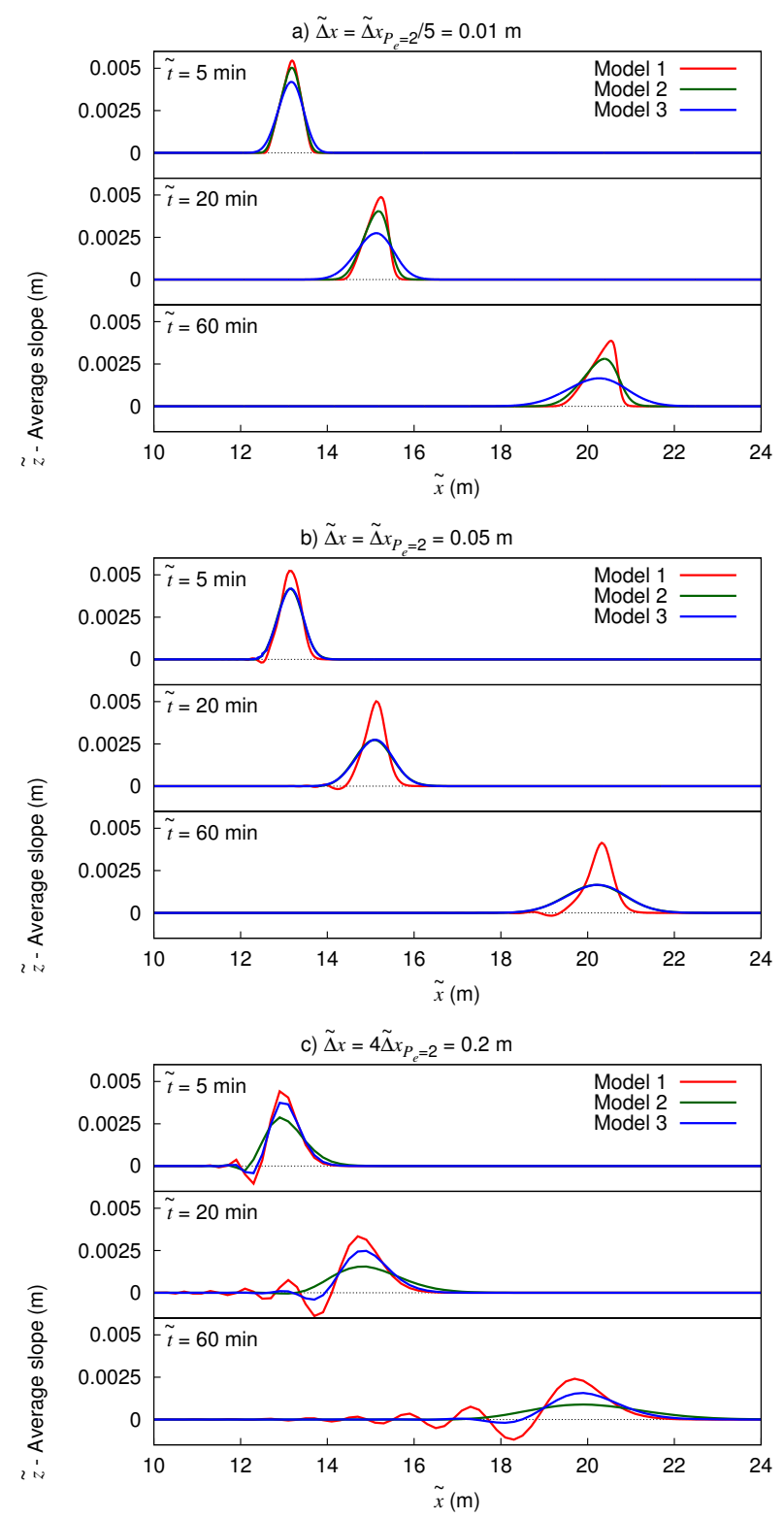

図-2 Case 1 における河床擾乱の伝搬過程の計算結果. 格子 幅がそれぞれ a) $0.01 \mathrm{~m}$ ，b) $0.05 \mathrm{~m}$ 及び，c) $0.2 \mathrm{~m}$ で ある. なお，縦軸は平均勾配を差し引いた標高である.

Model 3 は非常に近い結果を示しており, 流砂への河 床勾配の影響が計算結果に有意な差を与えていないこ とがわかる．また，格子幅が粗いケースにおいてアン ダーシュートがみられるものの, この不安定性は直ち に消失し，安定した計算が実現されている.

c) Case $4 \quad\left(F_{r}>1\right)$

図-5に，流れが射流条件である Case 4 の結果を示 す. Model 1, 3 における結果は, 河床擾乱が上流側に 伝搬することを除けば，流れが常流の場合と同じよう な傾向が確認できる．しかしながら，射流におけるケー スでは, 風上差分を適用した Model 2 による計算結果 は非常に不安定であった。 $\tilde{\Delta x}=0.05 \mathrm{~m}, 0.2 \mathrm{~m}$ のケース では初期に与えた河床擾乱が上流側に移動しながら不
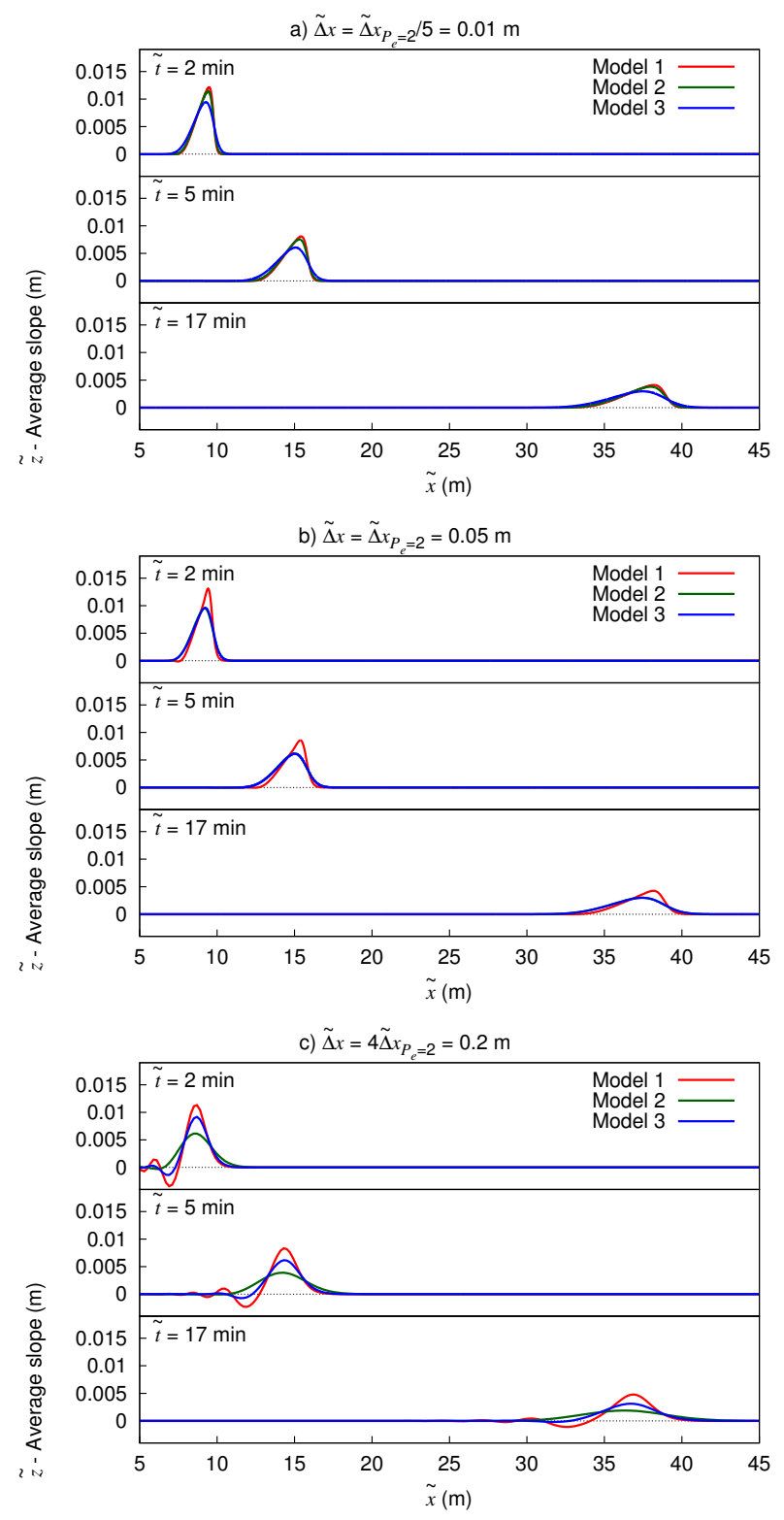

図-3 Case 2 における河床擾乱の伝搬過程の計算結果. 格子

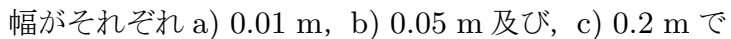
ある. なお，縦軸は平均勾配を差し引いた標高である。

安定となり，発散していることがわかる．この傾向は 格子幅が小さいほど大きく, $\tilde{\Delta x}=0.01 \mathrm{~m}$ のケースでは 数值解を得ることが困難であった。

\section{（2）河床勾配と風上化による河床拡散作用の関係}

計算結果より, Case 3 以外のケースでは Model 1 の 河床拡散作用が最も小さいことがわかる. 一方, 風上差 分を適用した Model 2 では, 流れが射流の場合を除い て, 安定した計算となっている. しかしながら, Model 2 の計算結果は計算格子依存度が大きく, 風上化によ る河床の数值拡散の影響度合いの大きさがうかがえる. 最後に中央差分を用い, 勾配の影響を考慮した Model 3 の結果を見ると, Model 1, 2 とは異なり, 全体的に 

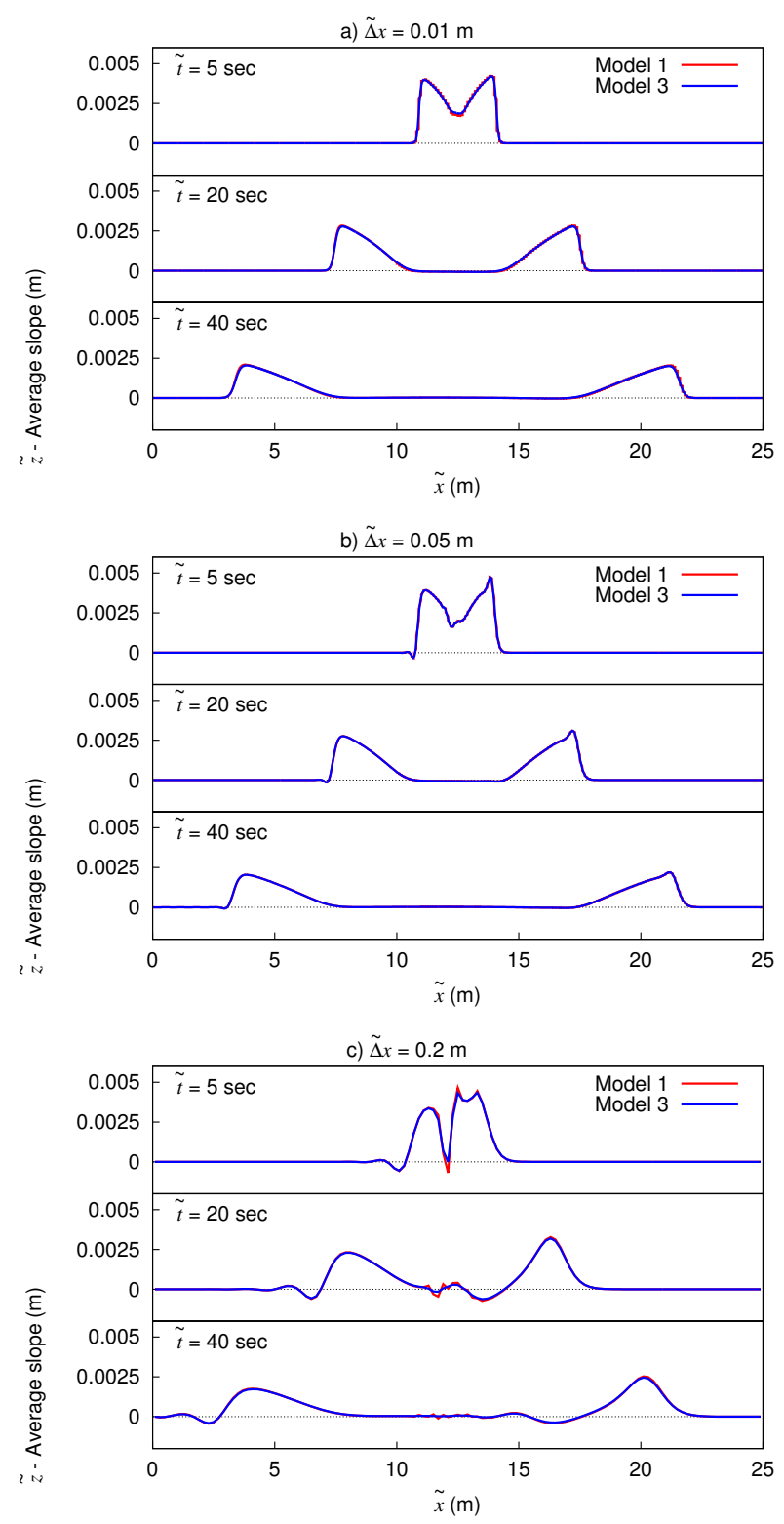

図-4 Case 3 における河床擾乱の伝搬過程の計算結果. 格子 幅がそれぞれ a) $0.01 \mathrm{~m}$ ，b) $0.05 \mathrm{~m}$ 及び，c) $0.2 \mathrm{~m}$ で ある. なお，縦軸は平均勾配を差し引いた標高である.

格子幅の影響が小さい傾向にある，特に着目すべきは, 式 (35) に示す $P_{e}=2$ を満たす格子幅における結果が, Model 2 の計算結果とほぼ一致していることである.こ れは, 流砂への河床勾配の影響による物理的な河床の 拡散作用と, 風上化による数值的な河床の拡散作用が 一致したことに他ならない，一方，格子幅が大きいケー スでは, Model 3 においても多少のアンダーシュート が生じており，河床擾乱の伝搬が不安定になっている. これは, $P_{e}>2$ となる格子幅では, 物理的な拡散の影 響が計算を安定させるために必要な拡散作用を満たし ていないためと考えられる。しかしながら, Model 1 で 示したように，従来指摘されている中央差分の不安定 性が小さいためか, Model 3 の結果から粗い格子にお
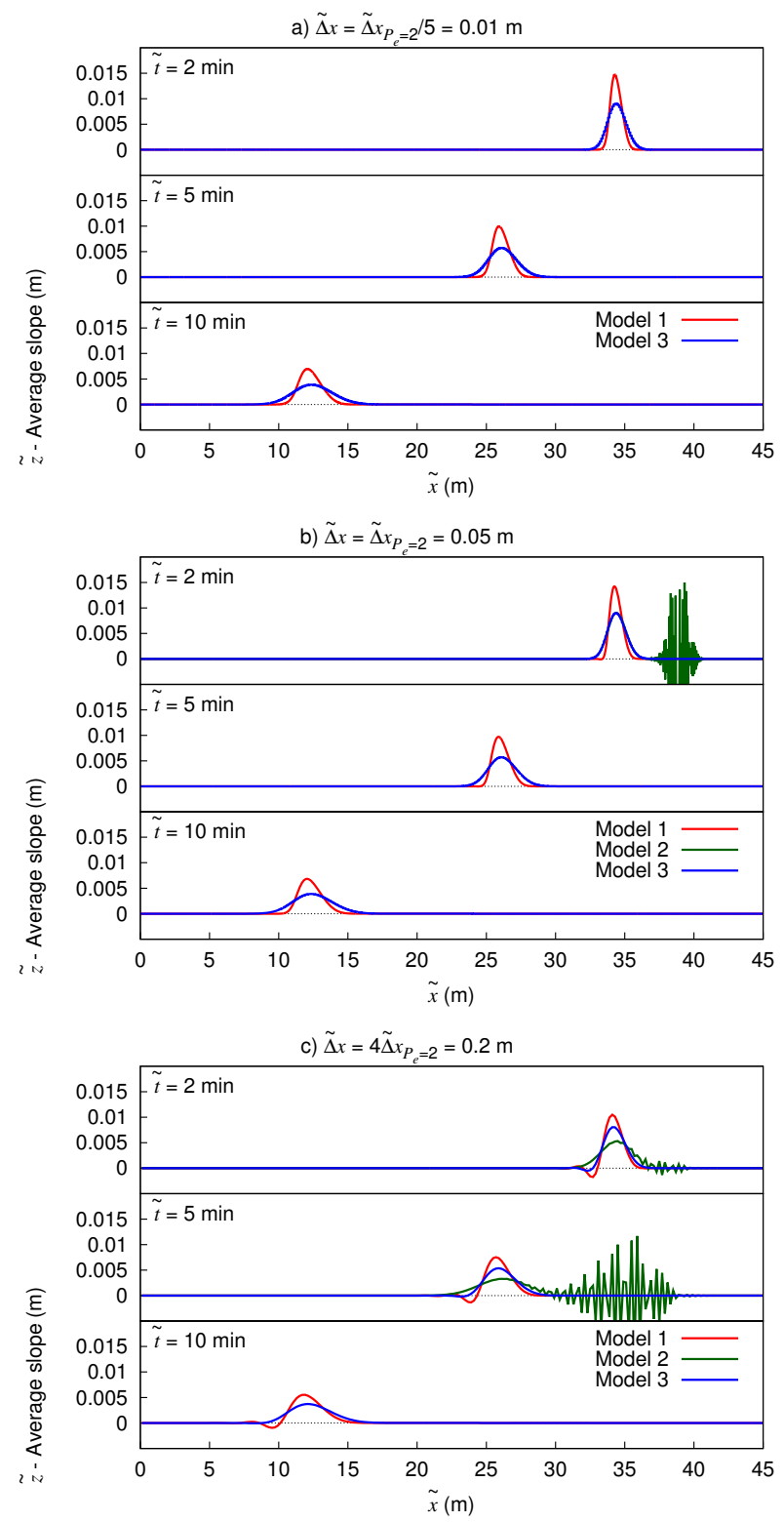

図-5 Case 4 における河床擾乱の伝搬過程の計算結果. 格子 幅がそれぞれ a) $0.01 \mathrm{~m}$, b) $0.05 \mathrm{~m}$ 及び，c) $0.2 \mathrm{~m}$ で ある. なお，縦軸は平均勾配を差し引いた標高である. 本ケースでは，Model 2 による結果は非常に不安定で あったことから, 数值解が発散したケースにおいては 図中に結果を示していないことに注意を要する。

いても安定的な計算が実現されていることがわかる.

この原因については不明確であるが，一つに格子系 にスタッガード格子を採用しているためと考えられる. スタッガード格子上では, 水深や河床と流速や流砂量 の定義点が一致しないため, 式 (28) の河床変動方程式 を導出する際に行う代入演算が差分レベルでは正確に は成り立たない. 特に, 式 (28) の導出過程から分かる ように, 河床擾乱の伝搬に重要な枠割を持つ移流項は, 流砂量の空間微分と流れの方程式を合わせることによ り導入される。したがって，差分レベルにおける誤差 は擾乱の伝搬機構に少なからず影響を持つことが予想 
される，言い換えれば，本来スタッガード格子系では， 式 (28) から考察される流砂量に対する風上化や中央差 分の理論が㛜密には定義できないとも考えられる。こ れは射流において風上差分によって河床が発散したこ ととも関連すると考えられる．射流においては式 (20) から分かるように, フルード数の増加により運動方程 式中の移流項のオーダーが増加する.これにより, 運 動方程式中の移流項のオーダーが水面勾配項よりも大 きくなり，移流項が流体運動に与える影響が大きくな る. 射流条件においては, 移流項の離散化精度と上記 スタッカード格子が持つ誤差が相互に増幅し, 計算が 不安定になっているものと推測される.しかしながら, 流体の数值計算に対してはスタッガード格子は依然有 効であるため，ここで示したような風上化の理論を用 いず，流砂量に局所勾配の影響を加味したうえで，式 (35) に示す $P_{e}<2$ を満たす格子幅を選択寸れば, 安定 した河床変動計算を行うことができると考えられる.

このように計算結果の解釈には多少不明確な点は残 るものの，式 (35) に示す $P_{e}<2$ を満たす格子幅におい て流砂空間微分に中央差分を導入し，流砂量に対する 局所勾配の影響を考慮したモデルを用いれば，数值拡 散を小さく押さえつつ, 物理的な河床拡散により数值 不安定性を合理的に散逸できることが示された. Model 3 は，風上化による場合分けや計算格子依存度を排除す ることが可能となるため, 河床変動計算モデルに対し て有利な方法であると考えられる。

\section{（3）河床擾乱の伝搬特性について}

$F_{r}=1$ のケースでは, Model 1 と 3 の結果がほぼ等 しく, 河床勾配の影響が河床擾乱の拡散に影響を与え ていないことが示唆される. また， $F_{r}<1$ の結果では, フルード数が 1 に近い Case 2 の方が, 中央差分を適用 した Model 1 における河床の不安定度合が小さい。こ れらの結果は, フルード数が 1 に近づくにつれて, 河 床勾配の影響とは別の物理的な河床の拡散作用が存在 していることを示唆している.

これを考察するために, Parker ${ }^{28)}$ を参考に河床変動 方程式を再構築する。まず，式 (25) 右辺の流砂への河 床勾配の影響を無視し, 式 (24) に代入すると次式が得 られる。

$$
h_{1}=\frac{i_{b}}{F_{r}^{2} C_{f 0} C_{f 2}}\left[\left(1-F_{r}^{2}\right) \frac{\theta_{01}}{3 C_{f 1} \tau_{* 0}} \frac{\partial z_{1}}{\partial t}+\frac{\partial z_{1}}{\partial x}\right](39)
$$

これを再び式 (25) に戻せば, 以下のような河床変動方 程式が得られる.

$$
\frac{\partial z_{1}}{\partial t}+B \frac{\partial^{2} z_{1}}{\partial x \partial t}+C \frac{\partial^{2} z_{1}}{\partial x^{2}}=0
$$

ここに,

$$
B=-\frac{1-F_{r}^{2}}{F_{r}^{2}} \frac{i_{b}}{C_{f 0} C_{f 2}}
$$

$$
C=-\frac{3 C_{f 1}}{F_{r}^{2}} \frac{\tau_{* 0}}{\theta_{01}} \frac{i_{b}}{C_{f 0} C_{f 2}}
$$

である.このような処理により, ソース項がない $x, t$ に 関する偏微分方程式となる. 式 (40) の特性方程式は次 式である.

$$
-B d x d t+C d t^{2}=0
$$

従って, 以下の二本の特性曲線を得る.

$$
t=\mathrm{const}, \quad x-\frac{C}{B} t=x-C_{z} t=\mathrm{const}
$$

すなわち, 式 (40) は二本の独立した特性曲線を持つ双 曲型の偏微分方程式である. ここに, 波動の伝搬速度 $C_{z}$ は,

$$
C_{z}=\frac{3 C_{f 1}}{1-F_{r}^{2}} \frac{\tau_{* 0}}{\theta_{01}}
$$

であり, 式 (28) の左辺第二項に示寸移流項の伝搬速度 と同様である. 一方で, $F_{r} \rightarrow 1$ の時, $B \rightarrow 0$ である から，特性方程式は

$$
d t=0
$$

に近づく，この時特性曲線は一本となり，方程式は楕円 型の性質を持つようになる. 特に, $F_{r}=1$ において,

$$
\frac{\partial z_{1}}{\partial t}+C \frac{\partial^{2} z_{1}}{\partial x^{2}}=0
$$

の拡散方程式となるため, 移流成分による不安定性は取 り除かれ，河床擾乱は次第に拡散していくことになる. これは，流れを等流とした場合に得られる方程式と同 一であり，等流条件に内在する河床の拡散作用である と考えられる. この時, 河床擾乱は西本ら ${ }^{12)}$ が示して いるように上下流方向に同一の振幅，波速を持って伝 搬していく，一方，河床変動方程式は双曲型の性質を 持たなくなるため不安性成分が消失し, 流れの計算が 安定していれば, 安定した河床変動計算が行えると考 えられる. 式 (28) と (40) を比較するとわかるように, 基本勾配が安息角程度の急斜面にならない限り，この 拡散係数 $C$ は流砂への局所勾配の影響から導出される 拡散係数よりもかなり大きい. その結果, Case 3 にお いて, Model 1 と Model 3 の差が小さかったものと考 えられる。このような楕円型方程式の性質により, フ ルード数が 1 に近いケースで, 河床擾乱伝搬の不安定 性が小さくなったものと考えられえる.

しかし一方で, この拡散項が 0 の場合は $z_{1}$ は常に変 化しないことから, 単に拡散作用を持つ項ではなく, 双 曲型方程式のソース項のような働きをすると考えられ る. $F_{r}$ が 1 近傍以外では, ソース項の役割が強くなり, 拡散項の性質は小さくなる。このことは, Case 1, 2 に おいて勾配項の影響を明確に確認できることからも明 らかである. 従って, フルード数が 1 近傍の点を除い ては，風上化もしくは流砂への河床勾配項の導入によ る河床の拡散作用を考慮することが重要となる. 


\section{（4）＼cjkstart流砂量式の違いによる影響}

既に議論したように，流砂量式への局所勾配の影響 は, 物理的な河床の拡散問題だけでなく, 数值的な安 定性の問題からも重要な要素である。一方，局所勾配 の影響を考慮した流砂量式はこれまでに数多くのモデ ルが提案されている24),29),30),31),32),33)。ここでは, そ の中でも Kovacs and Parker 式24)を取り上げ，上記議 論に対する Fredsøe 式 ${ }^{23)}$ との違いについて考察する.

微小な公配について線形化された Kovacs and Parker 式は以下のようである34)。

$$
\begin{aligned}
\frac{\tilde{q}_{b}}{\sqrt{s g \tilde{d}^{3}}}= & \frac{a^{1 / 2}}{\mu_{c}} \frac{1}{1+\frac{1}{\mu_{c}} \frac{\partial \tilde{z}}{\partial \tilde{x}}}\left[\tau_{*}-\tau_{* c}\left(1+\frac{1}{\mu_{c}} \frac{\partial \tilde{z}}{\partial \tilde{x}}\right)\right] \\
& \times\left[\tau_{*}^{1 / 2}-\tau_{* c}^{1 / 2}\left(1+\frac{1}{2 \mu_{c}} \frac{\partial \tilde{z}}{\partial \tilde{x}}\right)\right]
\end{aligned}
$$

ここで，基本流砂量を

$$
\begin{aligned}
\tilde{q}_{b 0}= & \frac{a^{1 / 2}}{\mu_{c}} \frac{1}{1-\frac{i_{b}}{\mu_{c}}}\left[\tau_{* 0}-\tau_{* c}\left(1-\frac{i_{b}}{\mu_{c}}\right)\right] \\
& \times\left[\tau_{* 0}^{1 / 2}-\tau_{* c}^{1 / 2}\left(1-\frac{i_{b}}{2 \mu_{c}}\right)\right] \sqrt{s g \tilde{d}^{3}}
\end{aligned}
$$

と定義し, 無次元化, 線形化を行うと, 流砂量の擾乱 成分は以下のようになる。

$$
\begin{gathered}
q_{b 1}=-2 C_{f 1} C_{i b}^{2}\left(\frac{\tau_{* 0}}{\theta_{01}}+\frac{\tau_{* 0}^{1 / 2}}{2 \theta_{02}}\right) h_{1} \\
-C_{i b} \frac{i_{b}}{\mu_{c}}\left[1+C_{i b}\left(\frac{\tau_{* c}}{\theta_{01}}+\frac{\tau_{* c}^{1 / 2}}{2 \theta_{02}}\right)\right] \frac{\partial z_{1}}{\partial x} \\
\theta_{02}=\tau_{* 0}^{1 / 2}-\tau_{* c}^{1 / 2}\left(1-\frac{i_{b}}{2 \mu_{c}}\right) \\
C_{i b}=1-\frac{i_{b}}{\mu_{c}}
\end{gathered}
$$

Fredsøe 式と同様の式展開により, 以下の線形化された 河床変動方程式を得ることができる.

$$
\begin{aligned}
& \frac{\partial z_{1}}{\partial t}+\frac{2 C_{f 1} C_{i b}^{2}}{1-F_{r}^{2}}\left(\frac{\tau_{* 0}}{\theta_{01}}+\frac{\tau_{* 0}^{1 / 2}}{2 \theta_{02}}\right) \frac{\partial z_{1}}{\partial x} \\
& =\frac{2 F_{r}^{2}}{1-F_{r}^{2}} \frac{C_{f 0} C_{f 1} C_{f 2} C_{i b}^{2}}{i_{b}}\left(\frac{\tau_{* 0}}{\theta_{01}}+\frac{\tau_{* 0}^{1 / 2}}{2 \theta_{02}}\right) h_{1} \\
& +\frac{C_{i b} i_{b}}{\mu_{c}}\left[1+C_{i b}\left(\frac{\tau_{* c}}{\theta_{01}}+\frac{\tau_{* c}^{1 / 2}}{2 \theta_{02}}\right)\right] \frac{\partial^{2} z_{1}}{\partial x^{2}}
\end{aligned}
$$

ここで流砂量式に Fredsøe 式を用いた場合に得られる線 形化河床変動方程式 (式 (28)) と大きく異なる点は, 右 辺第二項に示す拡散項の拡散係数にシールズ数に依存 しない部分があることである。この影響が安定計算に 与える影響を考察するために, 上記方程式より $P_{e}=2$

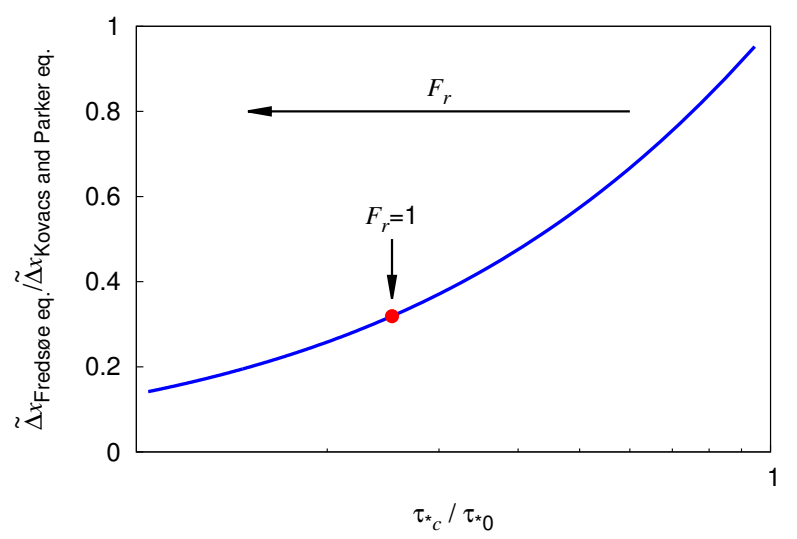

図-6 規格化された限界シールズ数 $\tau_{* c} / \tau_{* 0}$ と流砂量式に Fredsøe 式，Kovacs and Parker 式を適用した場合の $P_{e}=2$ を満たす格子幅の比. 図中の赤丸の点は $F_{r}=1$ に相当する点を示しており, この点では $P_{e}=2$ を満た 寸格子幅が 0 となるため, 不連続点となる.

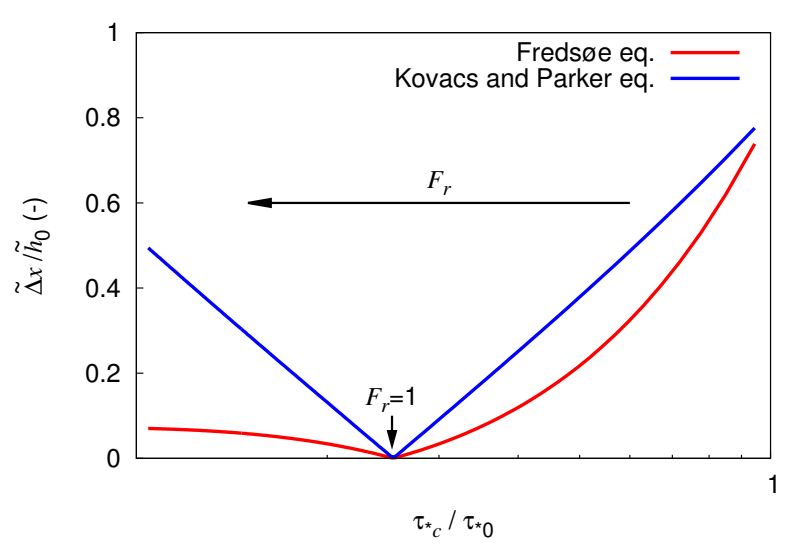

図-7 規格化された限界シールズ数 $\tau_{* c} / \tau_{* 0}$ と流砂量式に Fredsøe 式，Kovacs and Parker 式を適用した場合の $P_{e}=2$ を満たす格子幅.

を満たす格子幅を求めると以下のようになる.

$$
\tilde{\Delta} x_{P_{e}=2}=\frac{\left|1-F_{r}^{2}\right|}{\mu_{c} C_{i b} C_{f 1}} \frac{1+C_{i b}\left(\frac{\tau_{* c}}{\theta_{01}}+\frac{\tau_{* c}^{1 / 2}}{2 \theta_{02}}\right)}{\frac{\tau_{* 0}}{\theta_{01}}+\frac{\tau_{* 0}^{1 / 2}}{2 \theta_{02}}} \tilde{h}_{0}
$$

流砂量式に Fredsøe 式, Kovacs and Parker 式を用いた 場合に得られる $P_{e}=2$ を満たす格子幅がどのような 関係にあるか，またそれが水理条件によりどのように 変化するかを調べる。ここでは，仮想的な条件として， $i_{b}=1 / 200, \tilde{d}=0.1 \mathrm{~m}, \mu_{c}=0.47$ を共通パラメータと し, 流量を変動させることで, 水理条件を変化させた.

図-6 は，両者の格子幅の比と規格化された限界シー ルズ数 $\tau_{* c} / \tau_{* 0}$ の関係である. 図より, 掃流力の小さい 条件では両者の格子幅の差は小さいものの, 掃流力の増 大に伴い両者の差が次第に大きくなることが理解され， 
Kovacs and Parker 式のほうが計算を安定化させるた めに必要な格子幅を大きくとれることがわかる．なお 図中において流量，すなわちフルード数の増加は右か ら左に推移し, 赤丸は $F_{r}=1$ に相当寸る点を示してい る. $F_{r}=1$ の点においては, 式(28), 式(54) から分か るように河床の伝搬速度が無限大となるため, $P_{e}=2$ を満たす格子幅は 0 となる。これは, 図-7 に示寸水深 で無次元化した $P_{e}=2$ を満たす格子幅と $\tau_{* c} / \tau_{* 0}$ の関 係からも理解される. 従ってこの点は厳密には不連続 点となるが，前節で説明したようにこの点近傍では，河 床変動方程式が持つ双曲型の性質が消失する. 従って, 安定計算のために必要な格子幅を議論する必要性は小 さく, 安定計算のために非現実的な小さい格子幅を用 いる必要はないと考えられる.

ここで議論したように流砂量式は安定計算に必要な $P_{e}<2$ を満たす格子幅に大きく影響する．このような 違いは, 山口・泉35)が説明しているように, 流砂量に対 する局所勾配の影響を如何にモデル化しているかに起因 する，すなわち，Fredsøe 式では勾配の影響は限界シー ルズ数を補正する形で考慮されている。これは, シール ズ数の増大に従い勾配の影響が小さくなることを意味 しており，シールズ数の大きい領域では局所河床勾配 に起因する河床の拡散作用は相対的に小さくなる。一 方, Kovacs and Parker 式では限界シールズへの補正 とともに，分母に勾配項があることから流砂量自体に 対して勾配の影響が作用する。したがって，シールズ 数の増加に伴い流砂量が増加しても, 普遍的に勾配の 影響が作用することになる。このように流砂量式に対 する勾配の影響のモデル化により，ここで議論してい る安定的な計算に必要な格子幅に大きな影響が現れる. 勾配の影響はそれ自体物理的なものであり, 現象を再 現するためには，物理的な背景より導出された適切な 流砂量式を用いることが必要である. どちらの式が流 砂量を正しく表しているかは, 本論文の主旨ではない が，流砂量自体に勾配の影響が含まれている式系のほ うが安定した計算には適している。しかしながら，安 定計算に必要とされる格子幅は水深スケール以下であ り, 要求される条件はそれほど容易ではないことに注 意が必要である.

\section{5. 結論}

本研究では, 浅水流方程式と平衡流砂量式を基本と した河床変動モデルの計算法について, 河床擾乱の伝 搬計算を通じて考察を行った，方程式系を線形化する ことで, 河床変動に対する双曲型の方程式を導出し, 河 床擾乱の伝搬特性について明らかにした。この方程式 の安定性は，移流と拡散の比を表す Péclet 数により規
定される.この方程式に対し, 数值不安定性を回避する ために導入される風上差分と, 流砂量式から導入され る物理的な拡散作用の相互関係を考察寸ると共に, 上 記議論に対する流砂量式依存性について検討した. 得 られた結論を以下に示す.

- 河床変動式中の流砂空間微分に中央差分, 流砂量 式に局所勾配の影響を考慮したモデルを, $P_{e}<2$ を満たす格子幅の下で離散化すれば，数值拡散を 抑制しつつ, 物理的な河床拡散により数值不安定 性を合理的に散逸させることができる.

- 流砂量式中に勾配の影響を考慮せず, 流砂空間微 分に中央差分, 風上差分を適用した場合, 河床擾 乱の伝搬に対する格子依存度が大きい，また，ス タッガード格子を適用した場合, 厳密には流砂空 間微分に風上差分を定義することができず，条件 によっては数值解が発散することが示唆された。

・フルード数が 1 近傍では, 河床変動方程式が持つ 双曲型の性質が小さくなり, 楕円型の方程式にな る. そのため, 流砂空間微分の離散化に対する数 值的問題を考慮せずとも, 流れ場が安定的に解け れば，河床擾乱の伝搬を安定的に計算できる.

- Fredsøe 式のような限界シールズ数のみに勾配の影 響を考慮した流砂量式では, シールズ数が大きく なるに従い勾配の影響が小さくなり，移流に対す る拡散の影響が相対的に小さくなるため, $P_{e}<2$ を満たす格子幅条件が厳しくなる。一方, Kovacs and Parker 式のように，限界シールズ数のみなら ず流砂量全体に対して勾配の影響を考慮した流砂 量式では, シールズ数の増加に伴い流砂量が増加 しても，流砂量全体に対する勾配の影響は普遍で あるため, $P_{e}<2$ を満たすためには有利な流砂量 式である.

\section{参考文献}

1) 黒木幹男, 岸力, 清水康行 : 河床変動の数值計算法に関 する研究, 第 17 回自然災害科学総合シンポジウム講演 論文集，pp.175-178，1980.

2) Struiksma, N., Olesen, K.W., Flokstra, C. and de Vriend, H.J. : Bed deformation in curved alluvial channels, Journal of Hydraulic Research, Vol. 23, pp.57-79, 1985.

3) Shimizu, Y. and Itakura, T. : Calculation of bed variation in alluvial channel, Journal of Hydraulic Engineering, Vol. 115, No. 3, pp.367-384, 1989.

4) Giri, S. and Shimizu, Y.: Numerical computation of sand dune migration with free surface flow, Water Resources Research, Vol.42, w10422, doi:10.1029/2005WR004588, 2006.

5) Nabi, M., de Vriend, H. J., Mosselman, E., Sloff, C. J. and Shimizu, Y. : Detailed simulation of morphodynamics: 1. Hydrodynamic model, Water Resources Research, Vol. 48, W12523, doi:10.1029/2012WR011911, 2012. 
6) 関根正人：土砂粒子の運動の解析を基礎とした河床波 の形成過程シミュレーションの試み, 土木学会論文集, No.691, pp.85-91, 2001.

7) Hajivalie, F., Yeganeh, A., Houshanghi, H. and Gotoh, H. : Euler-Lagrange model for scour in front of vertical breakwater, Applied Ocean Research, Vol. 34, pp. 96-106, 2012.

8）笠原孟, 清水康行, 木村一郎, 山口里実: 個別要素法を用 いた河床変動計算, 土木学会論文集 B1（水工学）, Vol. 68, No. 4, pp.I_1201-I_1206, 2012.

9) Callander, R.A. : Instability and river channels, Journal of Fluid Mechanics, Vol. 36, pp.465-480, 1969.

10) Ikeda, S., Parker, G. and Sawai, K. : Bend theory of river meanders. Part1. Linear development, Journal of Fluid Mechanics, Vol. 112, pp.363-377, 1981.

11) 大川秀典, 清水康行, 藤田睦博, 橋本識秀: FDS 法を 用いた開水路の河床変動計算，水工学論文集，第 42 巻, pp.685-690, 1998.

12) 西本直史, 森明巨，板倉忠興，田原達人：FDS 法による 1 次元河床変動解析, 土木学会論文集, No. 677/II-55, pp.103-113, 2001.

13) Roe, P.L. : Approximate Riemann Solvers, parameter vectors and difference schemes, Journal of Computational Physics, Vol. 43, pp.357-372, 1981.

14) Goutiére, L., Soares-Frazão, S., Savary, C., Laraichi, T. and Zech, Y. : One-dimensional model for transient flows involving bed-load sediment transport and changes in flow regimes, Journal of Hydraulic Engineering, Vol. 134, No. 6, pp.726-735, 2008.

15) Harten, A., Lax, P.D. and van Leer, B. : On upstream differencing and Godunov-type schemes for hyperbolic conservation laws, SIAM Review, Vol. 25, pp.35-61, 1983.

16) Hudson, J., Damgaard, J., Dodd, N., Chesher, T. and Cooper, A. : Numerical approaches for 1D morphodynamic modelling, Coastal Engineering, Vol. 52, pp.691-707, 2005.

17) Long, W., Kirby, J.T. and Shao, Z. : A numerical scheme for morphological bed level calculations, Coastal Engineering, Vol. 55, pp.167-180, 2008.

18) Liu, X.D., Osher, S. and Chan, T. : Weighted essentially non-oscillatory schemes, Journal of Computational Physics, Vol. 115, pp.200-2012, 1994.

19) Cordier, S., Le, M.H. and Morales de Luna, T. : Bedload transport in shallow water models: Why splitting (may) fail, how hyperbolicity (can) help, Advances in Water Resources, Vol. 34, No. 8, pp.980-989, 2011.

20) Siviglia, A., Stecca, G., Vanzo, D., Zolezzi, G., Toro, E.F. and Tubino, M. : Numerical modelling of twodimensional morphodynamics with applications to river bars and bifurcations, Advances in Water Resources, Vol. 52, pp. 243-260, 2013.

21) Lesser, G.R., Roelvink, J.A., van Kester, J.A.T.M. and Stelling, G.S. : Development and validation of a three-dimensional morphological model, Coastal Engineering, Vol. 51, pp.883-915, 2004.

22) Meyer-Peter, E. and Müller, R. : Formulas for bedload transport, IAHSR, Report on the Second Meeting, Vol. 3, pp.39-64, 1948.

23) Fredsøe, J. : On the development of dunes in erodible channels, Journal of Fluid Mechanics, Vol. 64, pp.116,1974 .

24) Kovacs, A. and Parker, G. : A new vectorial bedload formulation and its application to the time evolution of straight river channels, Journal of Fluid Mechanics, Vol. 267, pp.153-183, 1994.

25) 泉典洋, 山口里実 : デューン - 平坦床遷移再考, 土木学 会論文集 B, Vol. 62, No. 4, pp.360-375， 2006.

26) 岩垣雄一 : 限界掃流力の流体力学的研究, 土木学会論文 集, Vol. 41, pp. 1-21, 1956.

27) Jang, C.L. and Shimizu, Y. : Numerical simulation of relatively wide, shallow channels with erodible banks, Journal of Hydraulic Engineering, Vol. 131, No. 7, pp.565-575, 2005.

28) Parker, G. : Morphodynamics e-Book: 1D Sediment Transport Morphodynamics with Applications to Rivers and Turbidity Currents, 2004.

29) 福岡捷二, 山坂昌成: 直線水路の交互砂州, 水理講演会 論文集，第 27 巻, pp.703-708, 1983.

30) 芦田和男, 江頭進治, 劉炳義 : 蛇行流路における流砂の 分級および河床変動に関する数值解析, 水工学論文集, 第 35 巻, pp.383-390, 1991.

31) 関根正人，小野了: 降雨による斜面浸食過程に関する数 值解析, 水工学論文集, 第 46 巻, pp.647-652, 2002.

32) Parker, G., Seminara, G. and Solari, L. : Bed load at low Shields stress on arbitrarily sloping beds: Alternative entrainment formulation, Water Resources Research, Vol. 39, No. 7, pp.1183-1192, 2003.

33) Chen, X., Ma, J. and Dey, S. : Sediment transport on arbitrary slopes: Simplified model, Journal of Hydraulic Engineering, Vol. 136, No. 5, pp.311-317, 2010.

34) 泉典洋, Pornprommin, A. : 振幅展開法を用いた砂州の弱 非線形解析, 土木学会論文集, No.712/II-60, pp.73-86, 2002.

35) 山口里実, 泉典洋:デューン-平坦床遷移過程にみられる亜 臨界分岐現象, 土木学会論文集, No. 740/II-64, 75-94, 2003.

(2013. 6. 6 受付) 


\title{
A MORPHODYNAMIC MODEL BASED ON A SHALLOW FLOW MODEL AND AN EQUILIBRIUM BEDLOAD TRANSPORT MODEL FOR CALCULATING BED EVOLUTION IN RIVERS
}

\author{
Toshiki IWASAKI, Yasuyuki SHIMIZU and Ichiro KIMURA
}

\begin{abstract}
The performance and stability of a numerical model which consist of a shallow water flow model and an equilibrium bedload transport model for calculating bed evolution in rivers is discussed. Such system equations which are generally adopted for calculating reach-scale river bed evolution have a hyperbolic feature. This fact has implied that upwind schemes to the space derivative of bedload transport in Exner equation are useful numerical methods to avoid bed instabilities in calculating the propagation of a small disturbance. Whereas, a bed diffusion effect which is essentially included in bedload dominated bed evolution has been modelled in equilibrium bedload transport models by considering the local slope effect to the bedload transport. The relation between the numerical and physical diffusion effect to the bed evolution should be investigated to understand the performance and stability of the model. A hyperbolic differential equation controlling the bed evolution was derived from the linearized system equations to understand the numerical characteristic of the propagation of the bed disturbance. We defined a Péclet number, $P_{e}$, as the ratio between the advective effect which controls the propagation of the bed disturbance and the diffusive effect associated with the bed slope effect. The effect of physical diffusion of the bed exceeds the effect of numerical diffusion by the upwind scheme to the bedload transport in the condition which $P_{e}<2$. The series of computations which focus on the propagation of hump type bed disturbance were conducted. The numerical results show that the calculation of propagating the bed disturbance can be physically stable without the upwind scheme when the grid size which satisfies $P_{e}<2$ is used. The grid size which is required such physically stable computation depends on how the bed slope effect is modelled in the bedload transport model.
\end{abstract}

